\title{
Comparison of Biochemical versus Morphological Changes of Human In-Vitro Stored and Postmortem Blood Specimens during Different Time Intervals
}

\author{
Eman Ahmed Alaa El-Din, Heba El Sayed Mostafa', and Mohamad Hosam El- \\ Din²
}

\footnotetext{
${ }^{1}$ Department of Forensic Medicine and Clinical Toxicology

${ }^{2}$ Department of Clinical Pathology
}

Faculty of Medicine, Zagazig University, Zagazig, Egypt

\begin{abstract}
Objectives: Estimation of post mortem interval (PMI) remains one of the most difficult challenges to a medicolegal expert. Postmortem biochemical changes may provide chemical markers to help more accurate determination of the postmortem interval. Obtaining postmortem blood samples is a simple and non invasive procedure. The purpose of the study was first, to compare time dependent changes in concentrations of $\mathrm{NADH}$, ammonia and uric acid versus morphological changes of white blood cells of in-vitro stored and postmortem blood samples for each time points $0,12,24,48$ and $72 \mathrm{~h}$. Second to find out an objective and quantitative standard for the estimation of postmortem interval. Materials and Methods: This study was carried out on blood samples collected from 30 healthy volunteers (group I) and 30 medicolegal autopsy cases (group II). Changes in concentration of NADH, ammonia and uric acid were recorded at $(0,12,24,48$ and $72 \mathrm{~h})$ of postmortem and storage periods. Also, blood films have been examined using a light microscope after staining with Giemsa stain to observe and compare morphological changes of white blood cells at the previous time intervals. Results: Concentrations of NADH, ammonia were significantly increased with time in (group II) while, uric acid showed no significance increase between both groups for the whole 72 hours. Also, degenerative morphological changes in white blood cells were in the form of pyknosis, cytoplasmic and nuclear vacuolation, nuclear fragmentation and disintegration. These changes were the same in both groups all over the time points of the study. Conclusion: From the previous results, it can be concluded that there were time dependent changes in NADH and ammonia levels, degenerative morphological changes of white blood cells. Also, there was a strong positive correlation between concentrations of plasma NADH and neutrophilic changes all over the time points of the study in the medicolegal autopsy cases.
\end{abstract}

Keywords Postmortem interval, morphological changes, white blood cells, post-mortem metabolic changes

\section{Introduction}

$\mathrm{D}$ etermination of the time of death is important in both criminal and civil cases. A precise estimation of postmortem interval (PMI) helps setting the time of the murder, verifying witnesses' statements and limiting the number of suspects. It is also of crucial importance in civil law, since it may influence the order of inheritance or possible commitments resulting from the order of deaths (Salam et al., 2012).
The postmortem interval (PMI) is the time between the death of an individual and the postmortem autopsy of the body. This variable is an essential component of any death investigation. Early PMI is up to $72 \mathrm{~h}$ postmortem, before the onset of putrefaction, while late PMI is any time after 3 days (Poloz and O'Day, 2011). Though the exact time of death can rarely be estimated on the basis of autopsy findings alone, an appropriate range of PMI can be deduced by intelligent 
interpretation of various changes that take place after death (Chandrakanth et al., 2013).

Following death, a complex series of biochemical and pathological processes are initiated resulting in a considerable alteration of the structure and composition of the human body. Because many of these changes occur sequentially, it has been proposed that the evaluation of the types and degrees of changes may enable estimation of time since death (Ferreira and Cunha, 2013).

To date several techniques have been used to determine the PMI based on subjective evaluation as decrease in body temperature, development of hypostasis and lividity, muscle relaxation, cadaveric spasm and blood coagulation. Besides the possibility of altering the crime scene, these methods are time consuming (Estracanholli et al., 2009). Hence there is a need to reexplore other objective methods such as biochemical, histological, serological assays (Garg et al., 2005).

Body fluids like pericardial fluid, cerebrospinal fluid, aqueous and vitreous humor, and synovial fluid show postmortem alterations in the levels of their electrolytes. These changes usually progress in a well designated manner until putrefaction sets in and can help forensic pathologist to estimate post mortem interval with a reasonable accuracy. These body fluids are located in closed compartments and thus, are not contaminated quickly after death (Arroyo et al., 2005).

The basic criteria which are necessary for methods to determine time of death are their being easy to apply and non invasive. It is easy to obtain postmortem blood samples even at the scene and it takes not more than a few minutes. The main problem is to provide a reliable method that could be based on blood analysis (Maeda et al., 2011).

Death is likely to result in very extensive biochemical changes in all body tissues due to lack of circulating oxygen, altered enzymatic reactions, cellular degradation, and cessation of anabolic production of metabolites. These biochemical changes may provide chemical markers helping in more accurate determination of the time since death (post-mortem interval) (Palmiere et al., 2012).

Nicotinamide adenine dinucleotide $(\mathrm{NAD}+)$ and NADH are substrates that have central roles in cellular metabolism and energy production as hydride-accepting and hydride-donating coenzymes in the citric acid cycle (Uemura et al., 2008).

Ammonia is formed in nearly all tissues and organs by normal amino acid and nucleotide catabolism. Antemortem ammonia is rapidly removed from circulation by the liver where it is converted to urea, or removed from skeletal muscle by the glucose-alanine cycle, leaving only traces in the bloodstream (Madea and Musshoff, 2007).

Uric acid is the end product of purine metabolism in humans. It is formed by the liver and excreted by the kidneys (65-75\%) and intestines (2535\%) (Álvarez-Lario and Macarrón-Vicente, 2010).
This study aimed first, to compare time dependent changes in concentrations of NADH, ammonia and uric acid versus morphological changes of white blood cells of in-vitro stored and postmortem blood samples for each time points $0,12,24,48$ and $72 \mathrm{~h}$. Second, to find out an objective and quantitative standard for the estimation of postmortem interval.

\section{Materials and Methods}

\section{A- Materials}

This study was carried out on 60 blood samples that have been collected from 30 apparently healthy volunteers (group I) and 30 medicolegal autopsy cases (group II) with known time of death.

\section{Exclusion criteria in apparently healthy volunteers}

Subjects with history of any oncological, hematological or infectious disease and whose ages below 20 or above 40 years old were excluded from the study.

\section{Exclusion criteria in autopsy cases}

Blood samples of cases with antemortem history of blood disease e.g. (hemophilia and leukemia), sever infections and liver and kidney diseases were excluded from the study.

An informed consent was taken was taken from:

1. Each subject in volunteer group before participating in the study.

2. From relatives of each cadaver from whom, blood sample was withdrawn.

\section{B- Study design}

The blood samples were divided into two groups as follow:

\section{Group I (Control)}

Blood samples ( $2 \mathrm{ml}$ from each volunteer) were collected at the same time from median cubital vein then labeled, enumerated and stored at room temperature for $0,12,24$, 48 and 72 hours. This group served as control group.

\section{Group II (Medico legal Autopsy Cases)}

Blood samples ( $2 \mathrm{ml}$ from each case) were drawn from the femoral vein according to the determined post mortem time intervals at $(0,12,24,48$ and $72 \mathrm{~h})$.

All the collected blood samples from both studied groups were subjected to:

1. Biochemical study for estimation of $\mathrm{NADH}$, ammonia and uric acid levels.

2. Morphological study of peripheral blood films.

\section{C- Methods}

\section{1- Biochemical study}

Blood sample, $2 \mathrm{ml}$ each, from (group I) were drawn from median cubital vein and as for (group II) from femoral vein and put in $5 \mathrm{~mL}$ sterile glass bottles with rubber bungs, in which $0.2 \mathrm{ml}$ of a $10 \%$ solution ethylene 
diamine tetraacetic acid (EDTA) K3 as anticoagulant had been added according to Bardale et al. ( 2010).

Collected blood samples from both groups were subjected to measurement of plasma concentration of each of NADH, ammonia and uric acid as follows:

a. NADH: The concentration of $\mathrm{NADH}$ was measured by using a spectrophotometric method based on the absorption of NADH at $340 \mathrm{~nm}$ according to Palmiere and Mangin (2012)

b. Ammonia: The concentration of ammonia was measured by using an enzymatic ammonia assay kit, (SigmaAldrich, Cat no. AA0100-1KT) follows the manufacturer's instructions (Neeley and Phillipson, 1988)

c. Uric acid: The concentration of uric acid was measured by using a Reflotron meter and uric acid strips (Roche Diagnostics, Cat no. 10745103202) according to the manufacturer's instructions (Heinig, and Johnson, 2006).

\section{2- Morphological study of blood film}

Peripheral blood films from both groups were prepared by staining with Giemsa stain. The peripheral blood smears were examined under the light microscope in an area of $1 \mathrm{~cm} \times 2 \mathrm{~cm}$ which was presumed to contain approximately 100 cells according to (Penttila and Laiho, 1981). The nuclear and cytoplasmic morphological changes in white blood cells have been recorded.

\section{3- Statistical analysis}

Statistical analysis was done by using SPSS 13.1 software program. Results were expressed as mean \pm standard deviation (S.D.). One-way analysis of variance (ANOVA) test was first carried out to test for any differences between the mean values of all groups. Statistical significance between two means was assessed by student's t-test at $\mathrm{P}<0.05$ (Mahajan, 1997).

\section{Results}

Demographic data of the studied groups are given in Tables 1 and 2. The cause of death of these cases was trauma e.g. (firearm injuries and mechanical injuries).

\section{1- Biochemical results (Table-3)}

\section{Plasma NADH}

Group II showed a significant increase $(p \leq 0.05)$ in plasma level of NADH as compared to that of group I. Also, plasma level of NADH in group II showed a significant increase $(\mathrm{p} \leq 0.05)$ from 12 hours postmortem $(5.2 \pm 0.8 \mathrm{mmol} / \mathrm{L})$ up to 72 hours postmortem $(26.9 \pm 1.1$ $\mathrm{mmol} / \mathrm{L}$ ), while there was no significant increase ( $\mathrm{p}$ $>0.05$ ) within group I all over the time points of the study.

\section{Plasma ammonia}

Group II showed a significant increase $(\mathrm{p} \leq 0.05)$ in plasma level of ammonia as compared to that of group I. Also, Plasma level of ammonia in group II showed a significant increase $(\mathrm{p} \leq 0.05)$ at 12 hours postmortem reaching $(2.6 \pm 0.3 \mathrm{mmol} / \mathrm{L})$ and remained significantly elevated by 72 hours postmortem $(11.8 \pm 0.4 \mathrm{mmol} / \mathrm{L})$, while there was no significant increase $(p>0.05)$ within group I all over the time points of the study.

\section{Plasma uric acid}

There was no significant difference $(\mathrm{p}>0.05)$ between both groups all over the time points of the study. Also, there was no significant increase $(p>0.05)$ within each group at different time intervals.

\section{2- Morphological study of peripheral blood films (Table-4)}

Analysis of blood films taken from both groups along 12, 24, 48 and72h PMI and storage time revealed the same degenerative morphological changes in white blood cells. At time zero $\mathrm{h}$ interval the blood films of both groups revealed normal morphological appearance (photomicrographs-1a, 2a, 3a and 4a).

\section{Neutrophils}

Pyknosis occurred during the first $12 \mathrm{~h}$, cytoplasmic and nuclear vacuolation after $12 \mathrm{~h}$, nuclear fragmentation started after $24 \mathrm{~h}$, disintegration was observed between 48 and $72 \mathrm{~h}$ (photomicrograph- $1 \mathrm{~b}, \mathrm{c}$ ).

\section{Esinophils}

Pyknosis, cytoplasmic and nuclear vacuolation occurred during the first $12 \mathrm{~h}$, nuclear fragmentation started after $12 \mathrm{~h}$ and disintegration was observed between 24 and $48 \mathrm{~h}$ (photomicrograph-2b, c, d, e).

\section{Monocytes}

Pyknosis occurred during the first $12 \mathrm{~h}$, cytoplasmic and nuclear vacuolation after $12 \mathrm{~h}$, nuclear fragmentation started after $24 \mathrm{~h}$ and disintegration was observed between 48 and $72 \mathrm{~h}$ (photomicrograph-3b,c,d,e).

\section{Lymphocytes}

Nuclear swelling and indistinctness in cytoplasmic cell membrane were observed between $24 \mathrm{~h}$ and $72 \mathrm{~h}$, while pyknosis, and nuclear fragmentation were observed after 48 and $72 \mathrm{~h}$, respectively(photomicrograph- $4 \mathrm{~b}, \mathrm{c}$ ).

The basophils are not taken into account in this study for their rarely observance in peripheral smears researches.

Correlation analysis showed that concentrations of plasma NADH and neutrophilic changes provided a strong positive correlation with PMI (Figure-1). While, there was no correlation between concentrations of plasma ammonia and white blood cells morphological changes (Figure-2). So, the neutrophilic changes and plasma level of NADH appeared to provide the best indicator of PMI (Table-5). 
Table-1: Demographic data of healthy volunteers (group I) $(\mathbf{n}=\mathbf{3 0})$

\begin{tabular}{|l|c|c|}
\hline \multirow{2}{*}{ In vitro storing period in hours } & \multicolumn{2}{|c|}{ Number of cases } \\
\cline { 2 - 3 } & Male & Female \\
\hline 0 & 3 & 2 \\
12 & 2 & 2 \\
24 & 3 & 4 \\
48 & 6 & 1 \\
72 & 4 & 3 \\
\hline
\end{tabular}

Table-2: Demographic data of medicolegal autopsy cases (group II) (n=30)

\begin{tabular}{|l|c|c|}
\hline \multirow{2}{*}{ Postmortem interval in hours } & \multicolumn{2}{|c|}{ Number of cases } \\
\cline { 2 - 3 } & Male & Female \\
\hline 0 & 3 & 2 \\
Less than 12 & 2 & 2 \\
Less than 24 & 3 & 4 \\
Less than 48 & 6 & 1 \\
Less than 72 & 4 & 3 \\
\hline
\end{tabular}

Table-3: ANOVA and LSD statistical analysis of plasma NADH, ammonia and uric acid concentrations at different PMIs in hours within group I (control) and group II (autopsy cases)

\begin{tabular}{|c|c|c|c|c|c|c|c|c|c|c|}
\hline \multirow{3}{*}{$\begin{array}{l}\text { Plasma } \\
\text { NADH (mmol } \\
\text { / L) }\end{array}$} & \multicolumn{5}{|c|}{ Group I (control) $(n=30)$} & \multicolumn{5}{|c|}{ Group II (autopsy cases) $(n=30)$} \\
\hline & $\mathbf{O} \mathbf{h}$ & $12 \mathrm{~h}$ & $24 \mathrm{~h}$ & $48 \mathrm{~h}$ & $72 \mathrm{~h}$ & $\mathbf{O} \mathbf{h}$ & $12 \mathrm{~h}$ & $24 h$ & $48 \mathrm{~h}$ & $72 \mathrm{~h}$ \\
\hline & $.35 \pm .08$ & $.37 \pm .09$ & $.4 \pm .1$ & $.4 \pm .13$ & $.39 \pm .1$ & $3.5 \pm 1.3^{\mathrm{a}}$ & $5.2 \pm .8^{\mathrm{a}, \mathrm{b}}$ & $10.4 \pm 1.07^{\mathrm{a}, \mathrm{c}}$ & $17.0 \pm .8^{\mathrm{a}, \mathrm{d}}$ & $26.9 \pm 1.1^{\mathrm{a}, \mathrm{e}}$ \\
\hline $\begin{array}{l}\text { Plasma } \\
\text { ammonia } \\
(\mathrm{mmol} / \mathrm{L})\end{array}$ & $.02 \pm .01$ & $.02 \pm .01$ & $.04 \pm .01$ & $.03 \pm .02$ & $.03 \pm .01$ & $1.06 \pm .007^{\mathrm{a}}$ & $2.6 \pm .3^{\mathrm{a}, \mathrm{b}}$ & $5.5 \pm .5^{\mathrm{a}, \mathrm{c}}$ & $7.5 \pm .4^{\mathrm{a}, \mathrm{d}}$ & $11.8 \pm .4^{\mathrm{a}, \mathrm{e}}$ \\
\hline $\begin{array}{c}\text { Plasma uric } \\
\text { acid }(\mu \mathrm{mol} / \mathrm{L})\end{array}$ & $159 \pm 2.1$ & $160 \pm 3.7$ & $157 \pm 7.2$ & $155 \pm 4.1$ & $156.7 \pm 3.13$ & $158.9 \pm .72$ & $159 \pm 1.3$ & $157 \pm 7.2$ & $157.7 \pm 1$ & $158.8 \pm .7$ \\
\hline
\end{tabular}

Data are expressed in terms of mean and standard deviation $(X+S D) ;$ a, significant increase compared to group I at $p \leq$ $0.0001 ; b$, significant increase compared to $0 h$ at $p \leq 0.000 ; c$, significant increase compared to $12 \mathrm{~h}$ at $p \leq 0.000 ; d$, significant increase compared to 24 h at $p \leq 0.000 ;$, significant increase compared to 48 at $p \leq 0.000$

Table-4: Morphplogical changes of white blood cells at different PMIs in hours within group I (volunteers) and group II (autopsy cases)

\begin{tabular}{|c|c|c|c|c|c|c|c|c|c|c|c|c|c|c|c|c|}
\hline \multirow{2}{*}{ PMI (h) } & \multicolumn{4}{|c|}{ Neutrophils } & \multicolumn{4}{|c|}{ Esinophils } & \multicolumn{4}{|c|}{ Monocytes } & \multicolumn{4}{|c|}{ lymphocytes } \\
\hline & $\mathbf{P} \%$ & $\mathrm{C} \%$ & N\% & D\% & $\mathbf{P} \%$ & $\mathrm{C} \%$ & $\mathbf{N} \%$ & D\% & $\mathbf{P} \%$ & $\mathrm{C} \%$ & $\mathrm{~N} \%$ & D\% & $\mathbf{P} \%$ & $\mathrm{C} \%$ & $\mathrm{~N} \%$ & D\% \\
\hline 0 & 0 & 0 & 0 & 0 & 0 & 0 & 0 & 0 & 0 & 0 & 0 & 0 & 0 & 0 & 0 & 0 \\
\hline 12 & 10 & 0 & 0 & 0 & 50 & 20 & 10 & 0 & 40 & 0 & 0 & 0 & 0 & 0 & 0 & 0 \\
\hline 24 & 20 & 25 & 10 & 0 & 60 & 40 & 30 & 20 & 55 & 45 & 20 & 0 & 0 & 0 & 0 & 0 \\
\hline 48 & 40 & 45 & 20 & 20 & 75 & 60 & 40 & 40 & 80 & 55 & 45 & 30 & 10 & 20 & 0 & 0 \\
\hline 72 & 55 & 50 & 40 & 45 & 90 & 80 & 70 & 80 & 85 & 75 & 75 & 75 & 30 & 35 & 25 & 0 \\
\hline
\end{tabular}

$P$, pyknosis; S, nucleus swollen, cytoplasm and cell membrane indistinct; $C$, cytoplasmic and nuclear vacuolation; $N$, nuclear fragmentation; $D$, disintegration

Table-5: Correlation analysis of plasma NADH, ammonia concentration and morphological changes of white blood cells of group II (autopsy cases) at different PMIs in hours

\begin{tabular}{|l|c|c|c|c|}
\hline \multirow{2}{*}{ Morphological changes of white blood cells } & \multicolumn{2}{|c|}{ Plasma NADH } & \multicolumn{2}{c|}{ Plasma ammonia } \\
\cline { 2 - 5 } & $\mathbf{r}$ & $\boldsymbol{p}$ & $\mathbf{R}$ & $\boldsymbol{P}$ \\
\hline Neutrophilic cahnges & 0.9 & $<0.001$ & 0.66 & 0.2 \\
\hline Eosinophilic cahnges & 0.86 & 0.06 & 0.66 & 0.2 \\
\hline Monocytes changes & 0.82 & 0.08 & 0.61 & 0.2 \\
\hline Lymphocytes changes & 0.71 & 0.1 & 0.64 & 0.2 \\
\hline
\end{tabular}




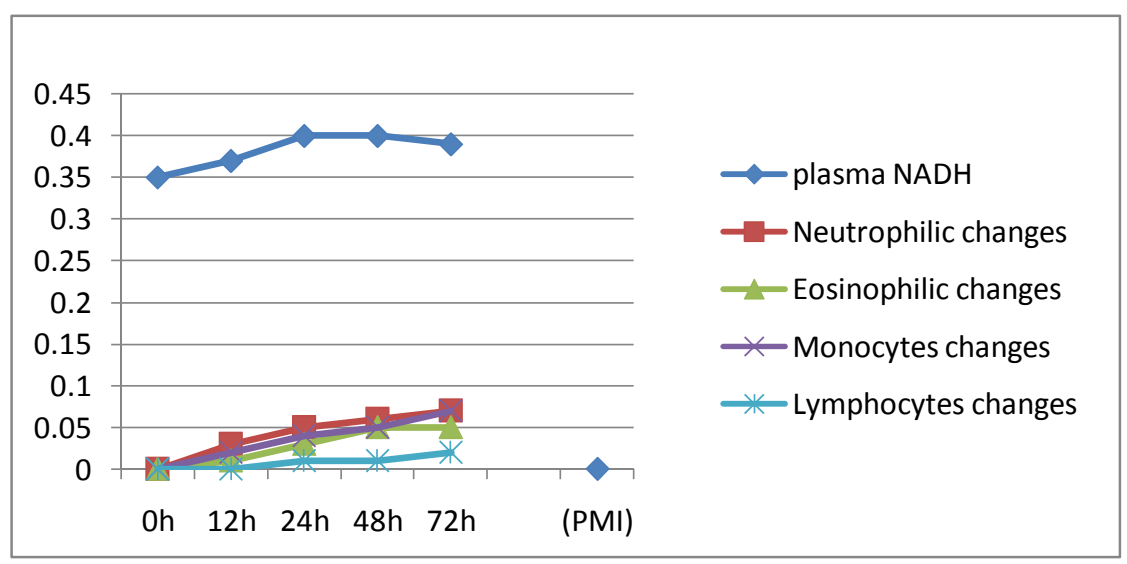

Figure-1: Correlation analysis of plasma NADH level and neutrophilic changes are positively correlated $(r=0.9)$.

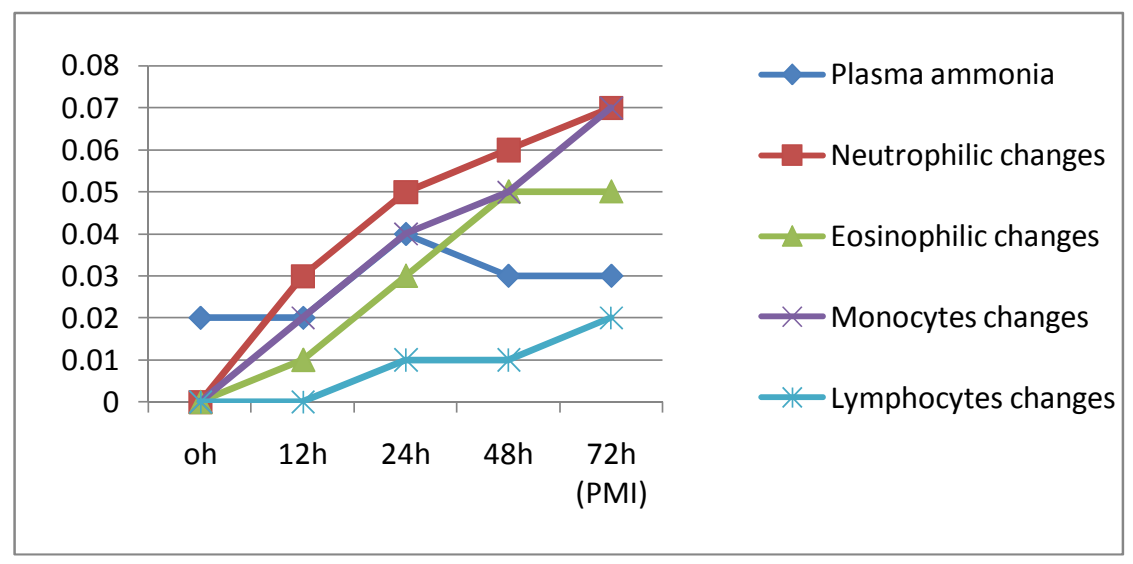

Figure-2: Correlation analysis of plasma ammonia level and morphological changes of white blood cells from 0 to 72 hours postmortem. No correlation.

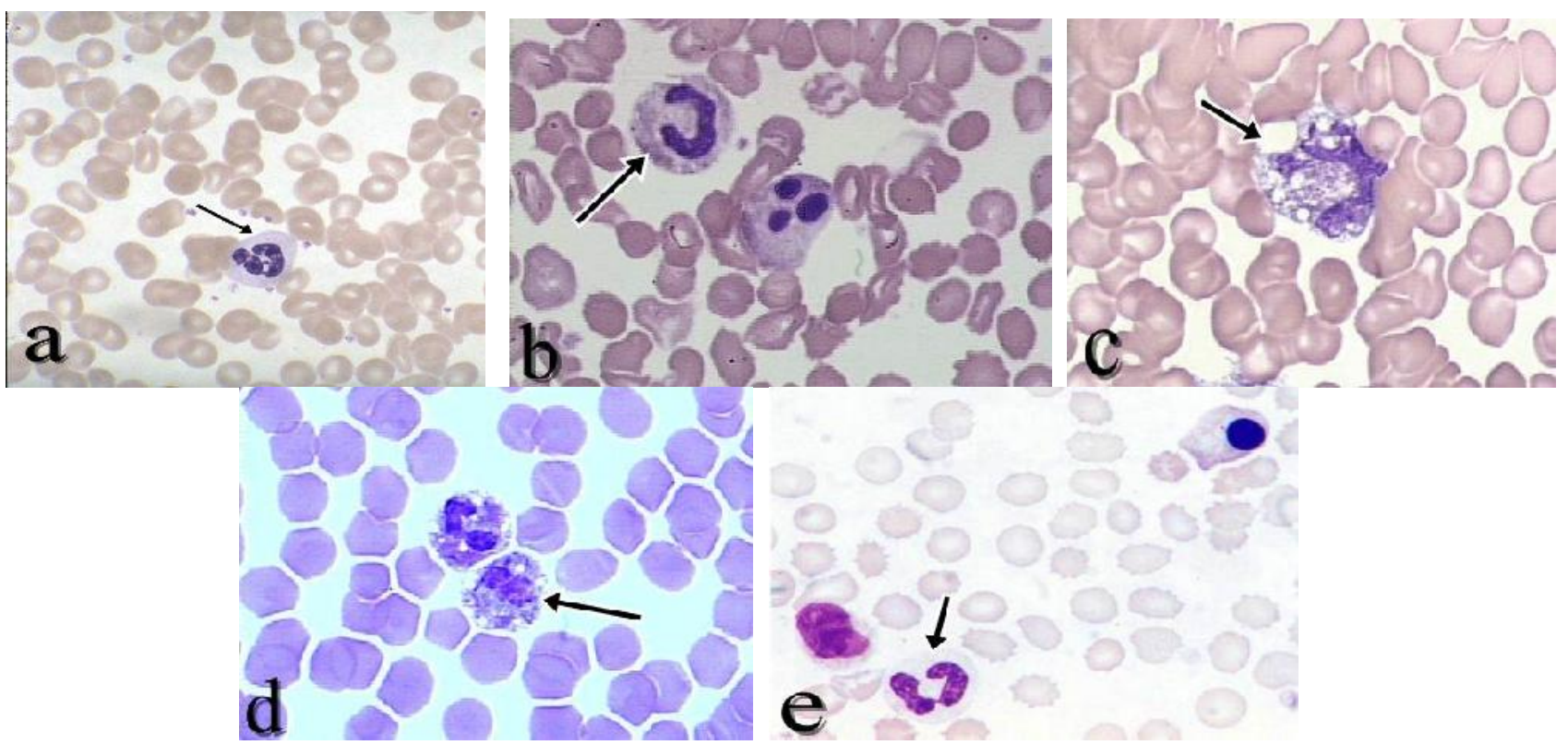

Photomicrograph-1: peripheral blood films showing morphological changes of neutrophils. (a) Normal 0h; (b) pyknosis 12 h; (c) cytoplasmic and nuclear vacuolation $12 \mathrm{~h}$; (d) nuclear fragmentation $24 \mathrm{~h}$; (e) disintegration (48-72h) (Giemsa $\times$ 1000). 


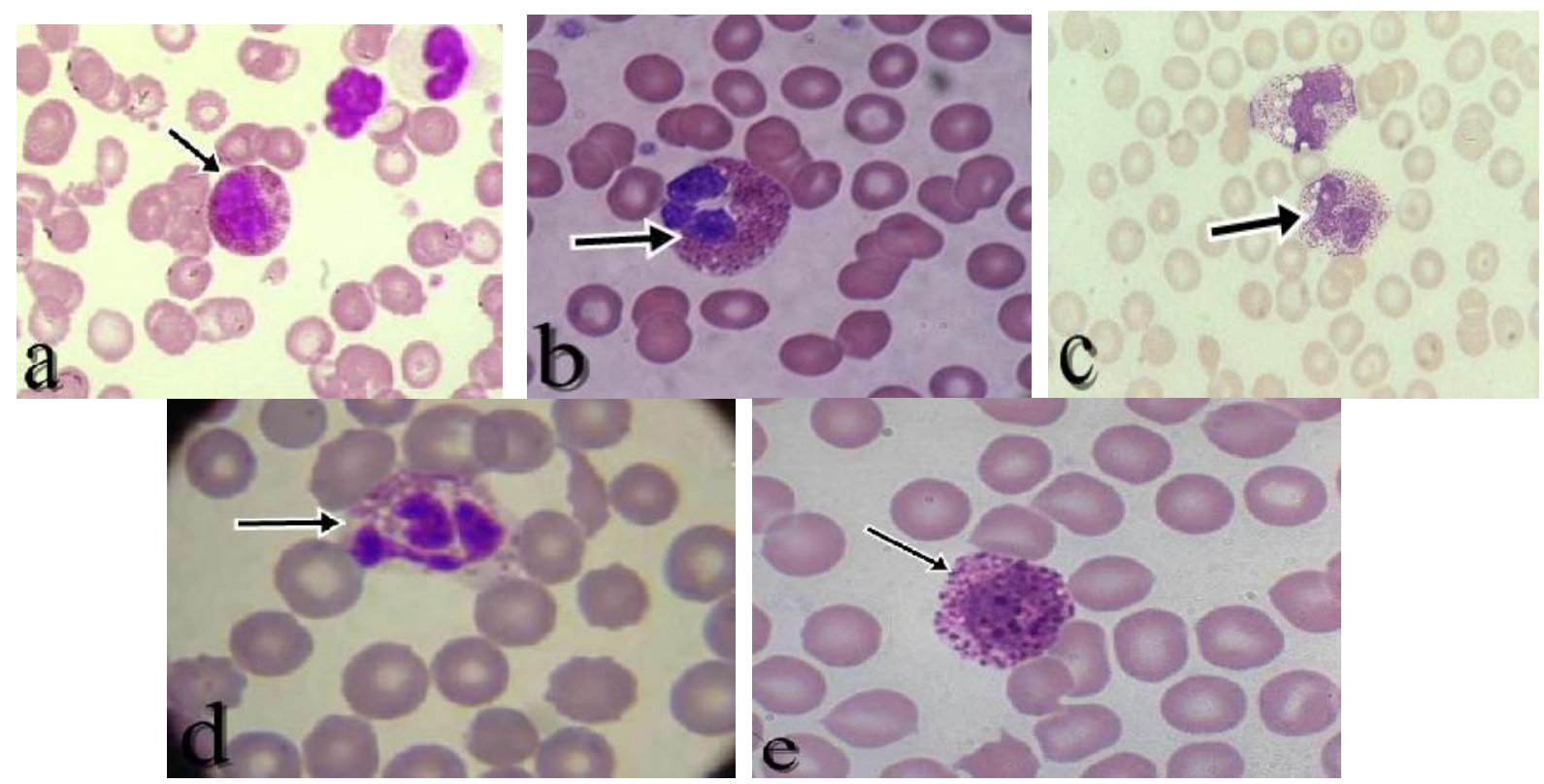

Photomicrograph-2: peripheral blood film showing morphological changes of eosinophils.(a) Normal 0 h; (b) pyknosis $12 \mathrm{~h}$; (c) cytoplasmic and nuclear vacuolation $12 \mathrm{~h}$; (d) nuclear fragmentation $12 \mathrm{~h}$; (e) disintegration (24-72 h) (Giemsa $\times 1000)$.

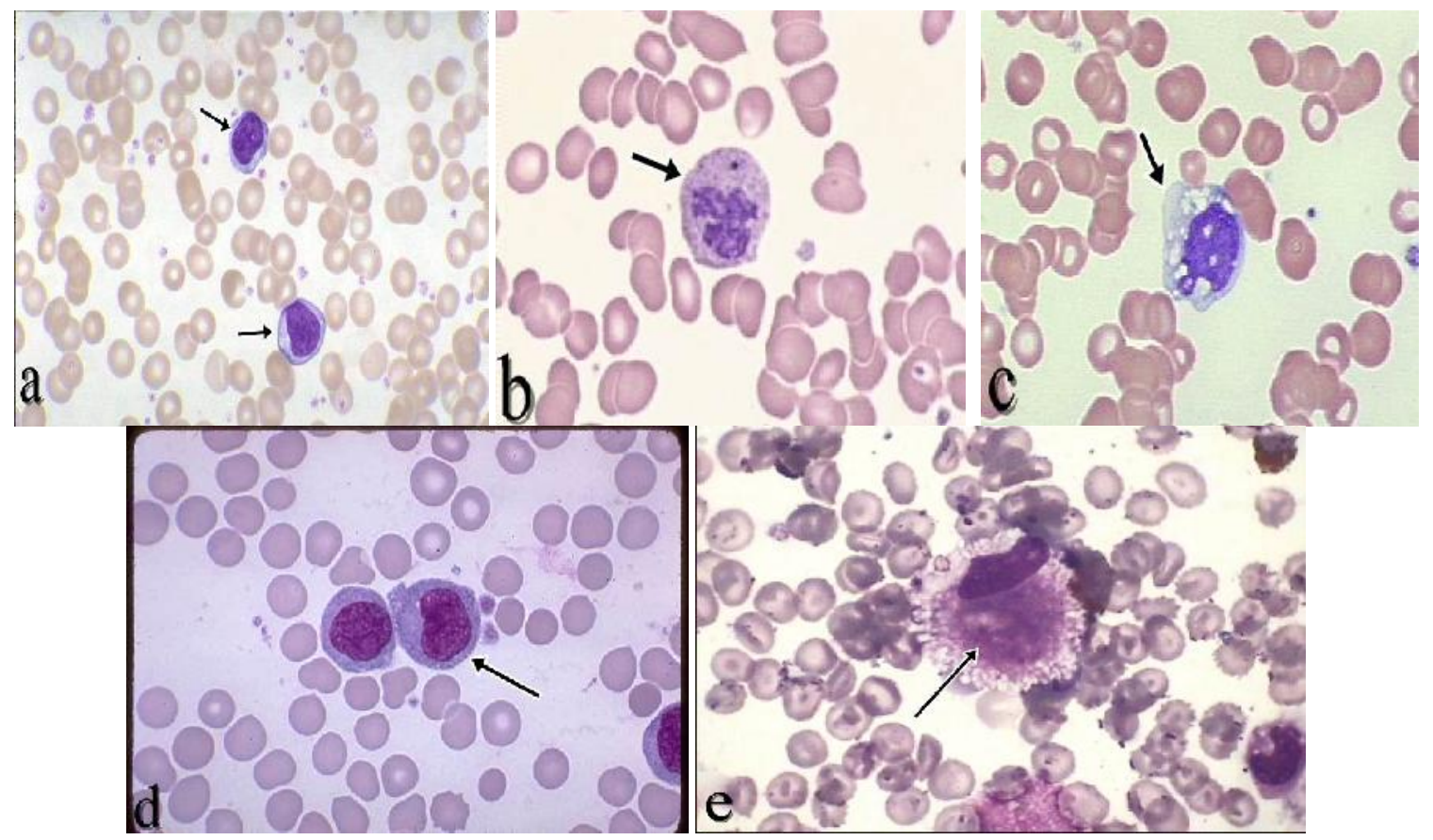

Photomicrograph-3: peripheral blood films showing morphological changes of monocytes. (a) Normal 0 h; (b) pyknosis $12 \mathrm{~h}$; (c) cytoplasmic and nuclear vacuolation $24 \mathrm{~h}$; (d) nuclear fragmentation $24 \mathrm{~h}$; (e) disintegration (48-72 h) $($ Giemsa $\times 1000)$. 


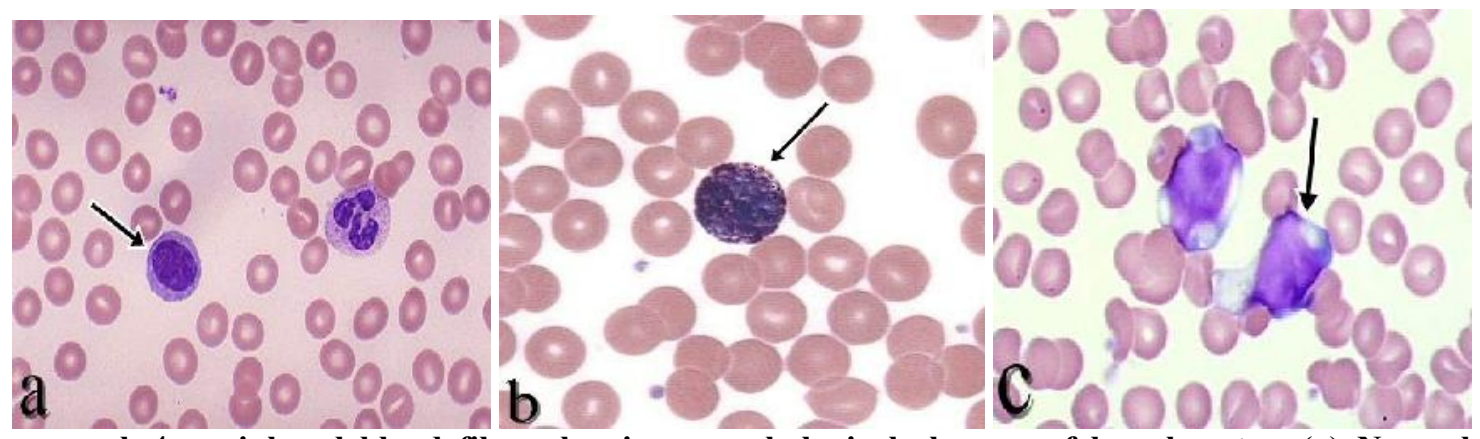

Photomicrograph-4: peripheral blood films showing morphological changes of lymphocytes. (a) Normal 0 h; (b) pyknosis $48 \mathrm{~h}$ (c) nucleus swollen, cytoplasm and cell membrane indistinct (48-72 h) $($ Giemsa $\times 1000)$.

\section{Discussion}

The determination of the post-mortem interval (PMI) is one of the most relevant measurements for forensic medicine. This need comes especially when considering a crime elucidation. To date several techniques have been used to determine the PMI, but most of them require some type of biopsy or collected biological fluids, followed by laboratory tests (Mathur and Agrawal, 2011).

Metabolic profiles in body fluids reflect endogenous changes and so changes that occur following death should manifest in altered metabolite profiles. The agonal period, supravital reactions (reactions occurring from the moment of death until cellular functions cease); leakage from cell degradation, and degradation of proteins should all be reflected in metabolite profiles. This means that analysis of metabolites from body fluids can provide insights into the changing biochemical environment post-mortem (Maeda et al., 2009).

The results of the present study showed that the concentration of plasma NADH of autopsy cases were significantly increased through postmortem time points as compared with control group.

These results are in accordance with Donaldson and Lamont (2012) who reported that, plasma NADH concentration increases rapidly after death and continue increasing 96 hours postmortem and also, suggested that different tissues release NADH into the blood stream as the tissues decompose, while in vitro stored blood has no other tissues which can release components into the blood.

To explain post mortem elevation in plasma NADH, Powers (2005) reported that after somatic death $\mathrm{NAD}+$ cannot be regenerated from $\mathrm{NADH}$ which accumulates due to anaerobic glycolysis and peroxisomal catabolism of fatty acids.

Also, plasma concentration of ammonia of autopsy cases increased rapidly and significantly as compared with control group over the first 12 hours and remained significantly elevated up to 72 hours postmortem.

These findings are in agreement with those obtained by Donaldson and Lamont (2014) who found that, the concentration of ammonia in plasma increases significantly after death with a rapid rise after 8 hours.

This can be attributed to the fact that proteins from different tissues may be released into the blood allowing more ammonia to be produced as those proteins are catabolised. Whereas in stored blood there are no other tissues to release proteins into the blood as they degrade, so the concentration of ammonia is lower (Murray et al., 2006).

The results of the present study revealed that plasma uric acid of control group and autopsy cases showed no significance increase above the normal range all over the time points of the study.

In consistent with these results Zhu et al. (2002) have reported that the serum uric acid remained relatively steady but low for the whole 96 hours postmortem, as uric acid is synthesized by xanthine oxidase which requires oxygen.

The results of the present study revealed degenerative morphological changes in white blood cells that occurred quite rapidly after death. These changes were in the form of pyknosis, nuclear vacuolation and nuclear fragmentation and disintegration started $12 \mathrm{~h}$ in neutrophils and eosinophils and monocytes. In lymphocytes these changes were observed after $24 \mathrm{~h}$. These degenerative morphological changes were the same during the first $72 \mathrm{~h}$ in both groups.

The results of the present study are consistent with Babapulle and Jayasundera (1993) who observed identifiable degeneration of neutrophils, eosinophils and monocytes after the first $12 \mathrm{~h}$ postmortem and the degenerative changes of lymphocytes began after $24 \mathrm{~h}$ postmortem. Also, Bardale and Dixit (2007) suggested that the lymphocytes are the most resistant blood cells to autolytic changes, the neutrophils are intermediate and monocytes and eosinophils are affected early.

Also, the results of the present study revealed that the concentrations of plasma NADH and neutrophilic changes had a strong correlation with PMI which was not provided with ammonia level and other morphological changes of white blood cells. So, neutrophilic changes and plasma level of NADH appeared to provide the best indicator of PMI. 
Like other tissue cells, blood cells also lose their normal morphology as a result of postmortem autolysis and putrefaction, and are unidentifiable in the last period. This degenerative process of blood cells can be useful for estimating postmortem interval (Laiho and Penttilä, 1981).

It is known that different cells of body die at different times after somatic death. The cellular death arises by an irreversible change in the internal environment of body consequent to death. This irreversible change in the internal environment is due to non-availability of oxygen, accumulation of carbon dioxide, $\mathrm{pH}$ change and accumulation of toxic products. Cells that are likely to be affected in blood by any irreversible altered internal environment are the normal blood cells i.e. red blood cells, white blood cells and platelets (Dokgöz et al., 2001).

\section{Conclusion}

From the current study it was concluded that, there were time dependent changes in plasma NADH and ammonia, also in the morphology of white blood cells after death. Also, concentrations of plasma NADH and neutrophilic changes had a strong positive correlation with PMI all over the time points of the study in the medicolegal autopsy cases. So, these postmortem changes can be useful for estimating the postmortem interval. The comparison needs to be carried out for longer postmortem intervals. Also the time dependent post mortem cellular changes have to be studied for identifying more potential markers for estimating different post-mortem intervals.

\section{References}

Álvarez-Lario B and Macarrón-Vicente J (2010): Uric acid and evolution. Rheumatology. 49: 20102015.

Arroyo A, Rosel P and Marron T (2005): Cerebrospinal fluid: postmortem biochemical study. Journal of clinical forensic medicine. 12(3): 153-156.

Babapulle C J and Jayasundera N P (1993): Cellular changes and time since death. Medicine, Science and the Law. 33(3): 213-222.

Bardale R and Dixit P G (2007): Evaluation of morphological changes in blood cells of human cadaver for the estimation of postmortem interval. Medico-Legal Update-An International Journal. 7(2): 35-39.

Bardale R, Dixit P G, Gharpure A G et al., (2010): Utility of blood smear and bone marrow smear examination in autopsy practice: A preliminary observation. Indian Internet Journal of Forensic Medicine and Toxicology. 8(3): 115-121.

Chandrakanth H V, Kanchan T, Balaraj B M et al., (2013): Postmortem vitreous chemistry-An evaluation of sodium, potassium and chloride levels in estimation of time since death (during the first $36 \mathrm{~h}$ after death). Journal of forensic and legal medicine. 20(4): 211-216.

Dokgöz H, Arican N, Elmas I et al., (2001): Comparison of morphological changes in white blood cells after death and in vitro storage of blood for the estimation of postmortem interval. Forensic science international. 124(1): 25-31.

Donaldson A E and Lamont I L (2012): Biochemistry changes that occur after death: potential markers for determining post-mortem interval. PloS one. 8(11): e82011-e82011.

Donaldson A E and Lamont I L (2014): Estimation of post-mortem interval using biochemical markers. Australian Journal of Forensic Sciences. 46(1): 8-26.

Estracanholli É S, Kurachi C, Vicente J R. et al., (2009): Determination of post-mortem interval using in situ tissue optical fluorescence. Optics express, 17(10): 8185-8192.

Ferreira M T and Cunha E (2013): Can we infer post mortem interval on the basis of decomposition rate? A case from a Portuguese cemetery. Forensic science international. 226 (1): 298-e1.

Garg S D, Arora A and Dubey B. P. (2005): A study of serum enzymal changes after death and its correlation with time since death. Journal of Indian Academy of Forensic Medicine. 27(1): 16-18.

Heinig M and Johnson R J (2006): Role of uric acid in hypertension, renal disease, and metabolic syndrome. Cleve. Clin. J. Med. 73(12): 10591064.

Laiho K and Penttilä A (1981): Autolytic changes in blood cells and other tissue cells of human cadavers. I. Viability and ion studies. Forensic science international. 17(2):109-120.

Madea B and Musshoff F (2007): Postmortem biochemistry Forensic Sci Int. 165: 165-171.

Maeda H, Ishikawa T and Michiue T (2011):Forensic biochemistry for functional investigation of death: concept and practical application. Legal Medicine. 13(2): 55-67.

Maeda H, Zhu B L, Ishikawa $T$ et al., (2009): Significance of postmortem biochemistry in determining the cause of death. Legal Medicine. 11: S46-S49.

Mahajan B K (1997): Significance of differences in means. $6^{\text {th }}$ edition. New Delhi: JAYPEE Brothers Medical Publishers. Pp. 130-155.

Mathur A and Agrawal Y K (2011): An overview of methods used for estimation of time since death. Australian Journal of Forensic Sciences. 43(4): 275-285.

Murray R K, Granner D K and Rodwell V W (2006): Catabolism of proteins and of amino acid nitrogen. 27 ed., Lange Medical Books, McGraw-Hill, New York, pp875- 84.

Neeley W E and Phillipson J (1988): Automated Enzymatic Method for Determining Ammonia 
in Plasma, with 14 day Reagent Stability. Clin. Chem. 3:1868-1869.

Palmiere C, Lesta M D, Sabatasso S et al., (2012): Usefulness of postmortem biochemistry in forensic pathology: illustrative case reports. Legal Medicine. 14(1): 27-35.

Palmiere C and Mangin P (2012): Postmortem chemistry update part II. Int J Legal Med. 126: 199-215.

Penttila A and Laiho K (1981): Autolytic changes in blood cells of human cadavers. II. Morphological studies Forensic Sci Int. 17: 121-132.

Poloz Y and O'Day D H (2011): The Use of Protein Markers for the Estimation of the Postmortem Interval. In Forensic Pathology Reviews, Humana Press, pp. 277-294.
Powers R H (2005): The decomposition of Human remains: a Biochemical perspective. In: Rich D E and Powers R H (eds) Forensic Medicine of the Lower Extremity:The Humana Press Inc, Totowa, pp. 1-13.

Salam H A, Shaat E A, Aziz M H et al., (2012): Estimation of postmortem interval using thanatochemistry and postmortem changes. Alexandria Journal of Medicine. 48(4): 335-344.

Uemura K, Shintani-Ishida K, Saka K et al., (2008): Biochemical blood markers and sampling sites in forensic autopsy. Journal of forensic and legal medicine. 15(5): 312-317.

Zhu B L, Ishida K, Quan L et al., (2002): Postmortem serum uric acid and creatinine levels in relation to the causes of death. Forensic Sci Int.125:5966.

\title{
الملخص العربي
}

\section{مقارنة التغيرات الكيميائية الحيوية و الشكلية بين عينات الدم البشرية المحفوظة (خارج الجسم الحي) و عينات الدم ما بعد الوفاة أثناء فترات زمنية مختلفة الدئ لئنة}

\author{
إيمان احمد علاء الاين و هبة العيد مصطفى' و محمد حسام الاين'
}

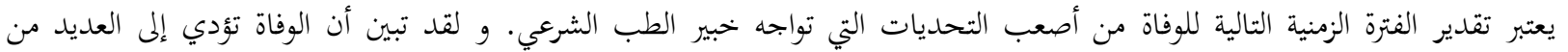

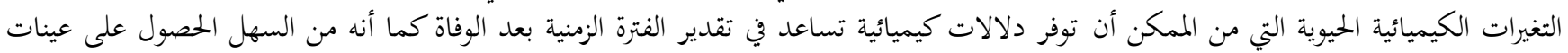

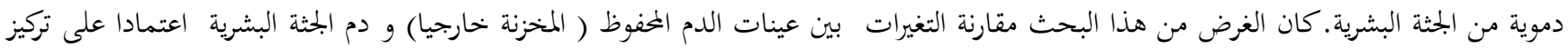

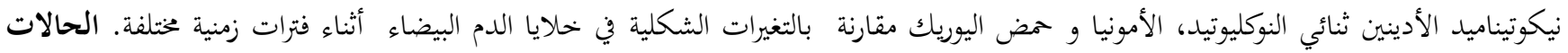

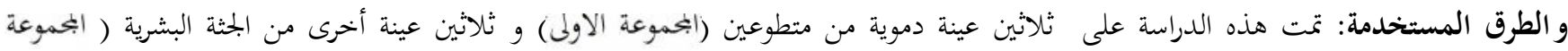

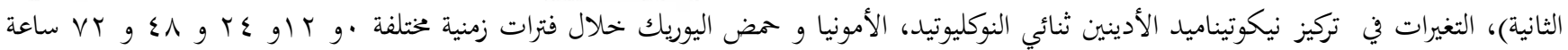

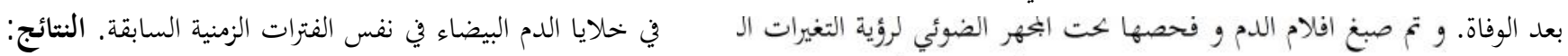

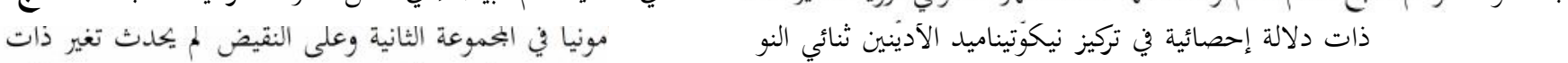

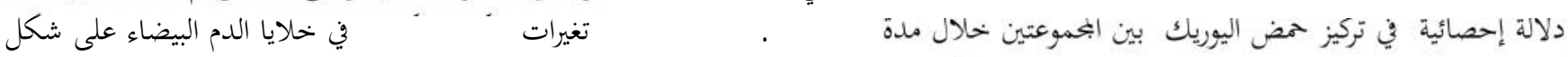

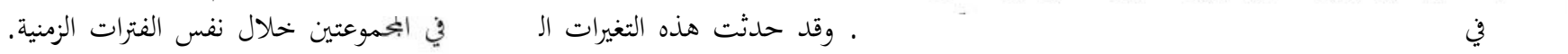

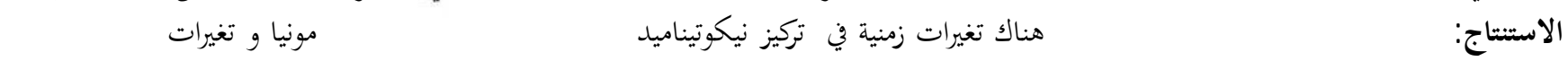

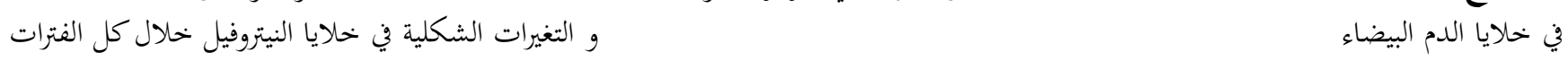

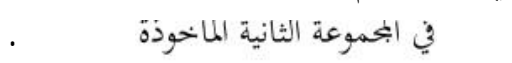

ا قمم الطب الشرعي والسموم الإكلينيكية - كلية الطب البشري - جامعة الزقازيق r قسم الباثولوجيا الإكلينيكية- كلية الطب البشري - جامعة الزقازيق 